\title{
Social Distancing in COVID-19: What Are the Implications for Musculoskeletal Problems and the Quality of Life?
}

\author{
Tae-Hyeong Kim, Hyun-Jun Jee, Chan-Woo Bae, Sil-Ah Choi \\ Department of Physical Therapy, Ansan University, Ansan, Republic of Korea
}

Purpose: This study examined the effects of social distancing in COVID-19 on musculoskeletal problems and the quality of life. Methods: One hundred and thirty-five subjects participated in this study and responded to an online survey on stress from the social distancing in COVID-19, computer and smartphone usages, musculoskeletal pain, and quality of life. The stress from social distancing was assessed by a Visual Analogue Scale (VAS). The Neck Disability Index (NDI), Oswestry Disability Index (ODI), and Boston Carpal Tunnel Questionnaire (BCTQ) were provided to assess the musculoskeletal pain, and Short Form-36 (SF-36) was provided to assess the quality of life. Frequency analysis, descriptive statistics, Pearson's correlation coefficient, and independent t-test were used for data analysis.

Results: Statistically significant, but low positive correlation stress from the social distancing (VAS) and NDI $(r=0.19, p<0.05)$ and ODI $(r=0.18, p<0.05)$, and negative correlation between stress from the social distancing (VAS) and SF-36 $(r=-0.17, p<0.05)$. The NDI score was significantly greater in the group with high stress than in the group with low stress from social distancing $(p<0.05)$.

Conclusion: This study is meaningful in that it evaluated, through the physical therapy approaches, the potential side-effects on physical and mental health in various social changes caused by COVID-19. The results of this study may be used as basic data in future studies related to COVID-19.

Keywords: COVID-19, Digital device, Musculoskeletal disorders, Quality of life, Social Distancing

\section{서 론}

코로나바이러스감염증-19 (코로나19)는 발열, 기침, 호흡곤란 및 폐렴 등 경증에서 중증까지 다양한 임상증상이 나타나는 호흡기 증후군 으로 2019년 12월 중국 우한시에서 발생하여 현재까지 국내뿐만 아니 라 전 세계적으로 확산되고 있다. 2020년 3월 세계보건기구는 코로나 19에 대하여 세계적으로 감염병이 대유행하는 상태를 일컫는 '팬데 믹(pandemic)'을 공식적으로 선언하며 전 세계를 대상으로 코로나 19 의 위험성을 알렸다. 2020 년 8 월 1 일 기준, 우리나라의 코로나 19 누적 확진자 수는 14,336 명으로, 이 중 격리해제자는 13,233 명(92.31\%)이며, 사망자는 301 명(치명률 $2.10 \%$ )으로 보고되고 있다.1

코로나19는 주로 비말 및 직접적 접촉을 통해 전파되는 것으로 알 려져 있어 올바른 손 씻기와 기침 예절이 기본적인 예방수칙으로 강 조된다. 2020년 3월 국내 코로나 19 확진자의 급증 이후 정부에서는 빠 른 전파력을 막고자 사회적 거리두기를 적극 권장하였다. ${ }^{2}$ 사회적 거 리두기는 개인 및 집단 간 접촉을 최소화하여 감염병 확산을 방지하
는 공중보건학적 통제전략으로, 이미 많은 국외 연구들에서 그 효과 가 입증되었다. ${ }^{3.4}$ 현재까지 사회적 거리두기는 근무환경, 교육체제, 생 활방식 등에서 다양한 변화를 일으키고 이에 따른 여러 가지 대응 방 안이 마련됨으로써 이미 '포스트 코로나(post corona)'라는 새로운 시 대를 맞이했다고 볼수 있다.

코로나 19 이후 가장 눈에 띄는 변화는 다양한 분야에서의 재택화 및 원격화가 이루어지고 있는 것이다. 직장에서는 사무실 밀집도 및 대인접촉의 최소화를 위해 IT기술을 이용한 원격근무를 실시하고 있으며, ${ }^{5}$ 교육 분야에서는 초·중·고등학교부터 대학교까지 등교 수업 을 중단하고 TV방송 채널, 온라인 실시간 프로그램, 강의녹화 업로 드 등의 방법으로 원격수업을 적극 추진하고 있다. ${ }^{6}$ 이 외에도 코로나 19는 사람들의 생활방식 및 취미활동 영역마저 변화시키고 있는데, 집단시설 이용이 제한됨에 따라 자유롭게 활동할 수 있는 외부의 환 경적인 요소가 통제되어 온라인을 통한 운동, 게임, 쇼핑, 종교 활동, 독서 등의 실내 활동이 급격히 증가하고 있다.7.8

하지만 이와 같은 다양한 형태로의 사회적 거리두기 실천이 감염병
Received Mar 9, 2021 Revised Mar 28, 2021

Accepted Apr 8, 2021

Corresponding author Sil-Ah Choi

E-mail silah88@naver.com
Copylight ( 2021 The Korean Society of Physical Therapy

This is an Open Access article distribute under the terms of the Creative Commons Attribution Non-commercial License (https:// creativecommons.org/license/by-nc/4.o.) which permits unrestricted non-commercial use, distribution, and reproduction in any medium, provided the original work is properly cited. 
확산 방지라는 효과적인 방법임에도 불구하고 외로움, 우울증, 신체 활동 및 생산성 감소와같은 부작용도 나타나고 있다.39,10 특히 코로나 19 로 인한 사회적 거리두기 상황에서 신체활동 감소와 온라인 활동 증가에 따른 근골격계 질환의 발생 가능성을 염두에 둘 필요가 있다. 이와관련하여 컴퓨터 및 스마트폰과 같은 기기들의 장시간 반복적인 사용으로 인한 신체적.정신적 건강상의 문제를 총칭하는 영상표시 단말기(Visual Display Terminal, VDT) 증후군을 예로 들 수 있다.

스마트폰을 선 자세에서 장기간 사용할 경우 목뼈 부위의 굽힘 각 도가 증가되어 목 주변 근육의 피로를 증가 시켜 통증을 유발하고 거 북목 증후군과 같은 근골격계 질환이 발생할 수 있다." 또한 스마트 폰을 앉아서 장시간 사용할 경우에는 등뼈와 허리뼈의 후방경사각 을 증가시키며 이러한 척추의 변형은 허리통증과 관련성이 높다.11,12 누운 자세에서는 선 자세와 앉은 자세보다 손에 더욱 안 좋은 영향을 끼칠 뿐 아니라 VDT증후군을 더 심하게 자각하게 된다. ${ }^{13}$ 컴퓨터게임 을 이용한 취미활동 시에는 손과 손가락의 장시간 사용에 따른 가이 온터널 증후군, 손목터널 증후군이 발생할 수 있다. ${ }^{14}$ 이 외에도 장기 간 고정된 자세로 컴퓨터 작업 시 근막통증 증후군, 퇴행성 관절염, 어깨돌림근띠 및 위팔두갈래근의 염증을 증가시킬 수 있다. ${ }^{15}$

이처럼 코로나 19 이후 신체활동은 감소하고 온라인 활동이 증가 하는 등 전반적인 사회적 분위기가 변화하였음에도 불구하고 신체 및 정신건강에 대한 예상 가능한 부작용에 대해 물리치료적 접근으 로 평가한 연구는 부족하다. 따라서 본 연구에서는 코로나19 예방 행 동 수칙인 사회적 거리두기로 인한 신체활동 및 사회참여 제약이 디 지털 기기 사용의 증가와 그에 따른 근골격계 문제 및 삶의 질에 어떠 한 영향을 미치고 있는지 온라인 설문조사 및 평가척도를 통해 알아 보고자한다.

\section{연구방법}

\section{1. 연구대상자 및 자료수집 방법}

본 연구는 서울 및 경기도에 거주하는 성인 남녀를 대상으로 설문지 를 통해 자료를 수집하였다. 설문기간은 2020년 8월 29일부터 9월 1일 까지 총 4 일간 실시하였고 국가에서 전국적으로 권고하는 사회적 거 리두기 기간임을 고려하여 비대면으로 연구를 진행하였다. 이를 위 해 설문내용은 구글 온라인 설문지를 이용하여 작성하였으며 설문 지의 배포는 한국인 대다수가 사용하는 메신저인 카카오톡을 통해 이루어졌다. 설문조사 전에 질문자는 연구의 취지와 목적, 방법을 설 명한 뒤 대상자의 자유의사를 고려하여 동의한 사람에 한해 자발적 으로 설문참여를 하도록 하였으며, 참여 도중 원치 않으면 언제든지 중지할 수 있음을 알렸다. 총 135 부의 설문지를 배포하였으며, 이 중 미응답 및 불성실한 응답 없이 135 명을 표본으로 하여 분석을 실시
하였다. 표본의 크기는 $G^{\star}$ Power software (ver. 3.1)를 통해 효과크기 0.25 , 검정력 0.80 , 유의수준 0.05 로 설정하여 필요한 최소 표본수는 120 명으로 산출되었고 이에 본 연구에 참여한 135 명은 적합한 표본 의 크기임을 확인하였다.

\section{2. 측정방법}

1) 코로나19로 인한 사회적 거리두기에 대한 자가평가

코로나19로 인한 사회적 거리두기에 대한 자가평가 문항은 사회적 거 리두기 준수 정도를 기준으로 구성하였다. ${ }^{10}$ 사회적 거리두기 준수 정 도는 '잘 지키고 있다', '가끔 벗어날 때도 있다(주 $1 / 2$ 회), '잘 지키지 않 는다로 답한다.

\section{2) 코로나19로 인한 사회적 거리두기에 대한 스트레스 정도}

코로나 19 로 인한 사회적 거리두기에 대한 스트레스의 정도를 파악하 기 위해 시각적 사상척도(Visual analogue scale, VAS)를 사용하였 다. ${ }^{10,16} \mathrm{VAS}$ 는 주관적인 평가 척도로 0 점에서 10 점까지 표시된 선 위 에 대상자 본인이 느끼는 스트레스의 정도를 직접 표시한다. 0 점에서 10 점으로 갈수록 스트레스가 심해지는 것을 의미하며, 0 점은 스트레 스가 전혀 없는 상태를, 10 점은 극도의 스트레스를 받고 있는 상태를 의미한다.

\section{3) 디지털 기기 사용에 대한 특성}

디지털 기기는 컴퓨터와 스마트폰으로 한정하였다. 컴퓨터 사용에 대한 설문지는 휴식, 컴퓨터 환경, 근골격계 질환을 연구한 설문지를 활용하여 구성하였고, ${ }^{17}$ 스마트폰 사용에 대한 설문지는 스마트폰 사 용량과 자세 특성에 관련된 근골격계 질환의 영향을 연구한 자료를 바탕으로 구성하였다. ${ }^{18}$ 이 중 컴퓨터와 스마트폰의 사용 목적과 하 루 평균 사용시간, 그리고 컴퓨터와 스마트폰 사용에 따른 근골격계 통증 경험 여부 문항을 선별하여 활용하였다.

\section{4) 근골격계 통증 및 기능장애 설문}

(1) 목 기능장애 평가(Neck Disability Index, NDI)

$\mathrm{NDI}$ 는 목의 통증과 기능장애를 측정하도록 고안된 것으로 총 10 개 의 문항으로 각 항목은 기능성 활동 여부에 관한 질문 7개, 증상에 관 한 질문 2 개, 집중에 대한 질문 1 개로 구성되어 있다. ${ }^{19} \mathrm{NDI}$ 점수는 각 항목 점수의 합으로 구하며 0-4점은 '장애 없음, 5-14점은 '경미한 장 애', 15-24점은 ‘중등도의 장애', 25-34점은 '중증 장애', 35점 이상은 '완 전한장애'로 분류한다.

(2) 허리 기능장애 평가(Oswestry Disability Index, ODI)

$\mathrm{ODI}$ 는 총 10 개의 문항으로 구성된 것으로 첫째, 허리통증 정도의 여부 
와 둘째, 개인위생, 물건 들기, 걷기, 앉기, 서 있기, 잠자기와 같은 일상생 활동작과 셋째, 성생활, 사회생활, 그리고 여행을 포함한 사회적 활동 에 대한 내용이 포함되어 있다..$^{20} \mathrm{ODI}$ 의 점수 합산 방식은 0 점에서부터 5 점까지 배정되며 총 점수는 50점으로 계산한다. 점수를 합산하여 총 점수가 0-10점은 '약간의 장애', 10-20점은 '중간의 장애', 20-30점은 '심한장애', 40-50점은 ‘침상 생활만 가능한 상태'로 해석된다.

(3) 손목터널 증후군 평가(Boston Carpal Tunnel Syndrome Questionnaire, $\mathrm{BCTQ})$

$\mathrm{BCTQ}$ 는 손목터널 증후군 환자를 대상으로 사용되는 설문지 중 가 장 유용성이 입증된 질병 특이 도구이다.21 문항은 평소의 손목 통증 정도, 낮이나 밤에 느끼는 통증 정도, 손 감각에 이상 증세에 대한 11 문항의 손목 증상 척도와 글쓰기, 단추 채우기, 독서할 때 책 들기, 장 바구니 들기 등에 대한 8 문항의 기능 상태 척도로 구성되어 있다. 점 수 합산 방식은 정상, 약간, 보통, 심각, 매우 심각으로 나뉘며 각 항목 을 1-5점으로 책정하여 평가한다.

\section{5) 삶의 질 평가(Short Form-36, SF-36)}

SF-36은 9개의 하부 영역과 36개 문항으로 구성되어 있다. 영역별 문 항은 신체적 기능 10 문항, 신체적 역할 제한 4 문항, 통증 2 문항, 사회 적 기능 2 문항, 정신건강 5 문항, 감정적 역할 제한 3 문항, 활력 4 문항, 일반건강 5 문항, 건강 상태의 변화 1 문항으로 구성되어 있다. 이 중 건 강 상태의 변화를 제외한 나머지 8 개 영역으로 건강 관련 삶의 질을 측정한다.22 각 문항은 건강에 가장 나쁜 영향을 미치는 내용을 1 점으 로 하여 문항에 따라 최고점은 2점에서 6점이다. 영역별 점수는 신체 적 기능의 경우 최저 10 점에서 최고 30 점까지 분포하며, 신체적 역할 제한 4-20점, 통증 2-12점, 사회적 기능 2-10점, 정신건강 5-25점, 감정적 역할제한 3-15점, 활력 4-20점, 일반건강 5-25점의 분포를 갖는다. 이렇 게 점수화한 각 문항을 항목별로 합산하며, 합산한 점수가 높을수록 좋은 건강 상태를 의미한다. ${ }^{23}$

\section{3. 자료분석}

수집된 자료는 SPSS 18.0 (SPSS, Chicago, IL, USA) 통계 프로그램을 이 Table 1. The general characteristic of subjects

$(\mathrm{N}=135)$

\begin{tabular}{lcc}
\hline & Number & Percentage (\%) \\
\hline Gender & 70 & 51.9 \\
M & 65 & 48.1 \\
F & & \\
Age (yr) & 108 & 80 \\
$20-30$ & 13 & 9.6 \\
$31-40$ & 4 & 3 \\
$41-50$ & 10 & 7.4 \\
Over 51 & & \\
\hline
\end{tabular}

용하여 다음과 같이 분석하였다. 첫째, 연구대상자의 일반적 특성, 코 로나19로 인한 사회적 거리두기에 대한 자가 평가, 디지털 기기 사용 량 특성은 빈도분석(빈도, 백분율)으로 분석하였다. 둘째, 코로나19로 인한 사회적 거리두기에 대한 스트레스 정도(VAS), 근골격계 통증 평 가척도(NDI, $\mathrm{ODI}, \mathrm{BCTQ})$, 삶의 질 평가(SF-36)에 대한 점수는 기술통 계(평균 \pm 표준편차)로 분석하였다. 셋째, 코로나 19 로 인한 사회적 거 리두기에 대한 스트레스 정도(VAS)와 디지털 기기 사용시간, 근골격 계 통증 평가척도(NDI, $\mathrm{ODI}, \mathrm{BCTQ}$ ), 삶의 질 평가(SF-36)와의 상관관 계는 피어슨 상관계수 $(\mathrm{r})$ 로 분석하였다. 상관계수 값은 0.25 미만일 경 우 상관성이 낮다(little), 0.25 -0.5일 경우 상관성이 보통(fair)이다', 0.50.75 일 경우 상관성이 중간(moderate)이다', 0.75 초과일 경우 상관성이 높다(good)'로 해석한다. ${ }^{24}$ 넷째, 코로나19로 인한 사회적 거리두기에 대한 스트레스 정도(VAS)의 평균점수를 기준으로 $+1 / 2$ 표준편차 이 상 범위에 속하는 그룹과 $-1 / 2$ 표준편차 이하 범위에 속하는 그룹 두 개로 나누어 디지털 기기 사용시간, 근골격계 통증 평가척도(NDI, $\mathrm{ODI}, \mathrm{BCTQ}$ ), 삶의 질 평가(SF-36)에 대한 점수 비교는 독립표본 t-검 정으로 분석하였다. ${ }^{25}$ 모든 유의 수준은 0.05 로 설정하였다.

\section{결 과}

\section{1. 연구대상자의 일반적 특성}

연구대상자 총 135 명에 대한 일반적 특성은 성별(남자/여자), 연령별 (20-30세/31-40세/41-50세/51세 이상)로 구분하여 각각 빈도와 백분율 로 나타내었다(Table 1).

\section{2. 사회적 거리두기 자가평가}

연구대상자 총 135 명에 대한 코로나 19 로 인한 사회적 거리두기 준수 정도는 '잘 지키고 있다(64.4\%)', '가끔 벗어날 때도 있다(33.3\%)', '잘 지 키지 않는다(2.2\%)순으로 나타났다(Table 2).

\section{3. 디지털 기기 사용에 대한 특성}

연구대상자 총 135명은 컴퓨터 사용 목적을 자료검색(59.3\%), 문서작 업(50.4\%), 게임(36.3\%), 채팅(20\%), 기타항목(36.3\%)으로 중복 응답하 였고 스마트폰 사용 목적을 메신저 및 문자(91.9\%), 게임(47.4\%), 웹 서 핑(74.8\%), 전화(75.6\%), 기타항목(31.9\%)으로 중복 응답하였다. 컴퓨터

Table 2. Self-evaluation about compliance in social distancing

$(\mathrm{N}=135)$

\begin{tabular}{lccc}
\hline & Extent & Number & Percentage (\%) \\
\hline Compliance in social & Always & 87 & 64.4 \\
distancing & Sometimes & 45 & 33.3 \\
& Hardly & 3 & 2.2 \\
\hline
\end{tabular}


Table 3. Digital device usage

$(N=135)$

\begin{tabular}{lccc}
\hline & Hour & Number & Percentage (\%) \\
\hline Computer & & & \\
Average Usage a day & Less 1 & 31 & 23 \\
& $1-2$ & 22 & 16.3 \\
& $2-3$ & 27 & 20 \\
& $3-4$ & 10 & 7.4 \\
& Over 4 & 45 & 33.3 \\
Pain & Yes & 72 & 53.3 \\
Smartphone & No & 63 & 46.7 \\
Average Usage a day & Less 30 min & 1 & \\
& 30 min-1 hr & 5 & 0.7 \\
& $1-2$ & 15 & 3.7 \\
& $2-4$ & 38 & 28.1 \\
& Over 4 & 76 & 56.3 \\
Pain & Yes & 63 & 46.7 \\
& No & 72 & 53.3 \\
\hline
\end{tabular}

와 스마트폰의 하루 평균 사용시간은 모두 '4시간 이상'에서 각각 $33.3 \%$ 와 $56.3 \%$ 를 차지하며 가장 높았다. 또한 컴퓨터와 스마트폰 사 용시간에 따른 통증 유무에 대한 응답은 '예'가 각각 $53.3 \%$ 와 $46.7 \%$ 를 보였다(Table 3).

\section{4. 사회적 거리두기 스트레스 정도와 디지털 기기 사용시간, 근골격계 통증 평가척도 및 삶의 질과의 상관관계}

연구대상자들의 사회적 거리두기에 대한 스트레스 정도(VAS)와 컴 퓨터 및 스마트폰 사용시간과의 관계는 각각 상관계수(r)의 값이 0.09 $(\mathrm{p}>0.05)$ 및 0.06 ( $\mathrm{p}>0.05)$ 을 보이며 낮은 양의 상관성을 보였다. 또한 근골격계 통증 평가척도인 $\mathrm{NDI}, \mathrm{ODI}, \mathrm{BCTQ}$ 와의 관계는 각각 상관계 수(r)의 값이 0.19 ( $\mathrm{p}<0.05), 0.18$ ( $\mathrm{p}<0.05), 0.05$ ( $\mathrm{p}>0.05)$ 를 보이며 낮은 양의 상관성을 보였다. 그리고 삶의 질(SF-36)과의 관계에서는 낮은 음 의 상관성 $(\mathrm{r}=-0.17, \mathrm{p}<0.05)$ 을 보였다(Table 4$)$.

\section{5. 사회적 거리두기 스트레스 정도에 따른 그룹 간 디지털 기기 사용시간, 근골격계 통증 평가척도, 삶의 질에 대한 점수 비교} 연구대상자들을 사회적 거리두기에 대한 스트레스 정도(VAS)의 평 균점수(6.87점)를 기준으로 $+1 / 2$ 표준편차 이상 범위에 속하는 그룹A (스트레스가 높은 그룹)와 $-1 / 2$ 표준편차 이하 범위에 속하는 그룹B (스트레스가 낮은 그룹)로 나누어 각각 변수들과의 점수를 비교한 결 과, 컴퓨터 및 스마트폰 사용시간에서는 그룹 간에 통계적으로 유의 한 차이가 없었으며 $(\mathrm{p}>0.05)$, 근골격계 통증 평가척도 중 $\mathrm{NDI}$ 에서는 그룹 간에 통계적으로 유의한 차이를 보였고 $(\mathrm{p}<0.05), \mathrm{ODI}$ 와 BCTQ 에서는 유의한 차이를 보이지 않았다( $\mathrm{p}>0.05)$. 삶의 질(SF-36)에서 또
Table 4. The coefficient of correlation ( $r$ ) between stress in social distancing and other factors

$(\mathrm{N}=135)$

\begin{tabular}{lc}
\hline$r$ & Stress in social distancing (VAS) \\
\hline Computer use hours & 0.09 \\
Smartphone use hours & 0.06 \\
$\mathrm{NDI}$ & $0.19^{*}$ \\
ODI & $0.18^{*}$ \\
BCTQ & 0.05 \\
SF-36 & $-0.17^{*}$
\end{tabular}

NDI: Neck Disability Index, ODI: Oswestry Disability Index, BCTQ: Boston Carpal Tunnel Syndrome Questionnaire, SF-36: Short Form-35, VAS: Visual Analogue Scale.

${ }^{*} p<0.05$

Table 5. Comparison between groups according to the extent of stress in social distancing

$(\mathrm{N}=135)$

\begin{tabular}{lccc}
\hline & Group A & Group B & $\mathrm{p}$ \\
\hline Computer use hours & $3.55 \pm 1.44$ & $3.00 \pm 1.55$ & 0.12 \\
Smartphone use hours & $4.20 \pm 0.86$ & $4.16 \pm 1.05$ & 0.88 \\
NDI* $^{*}$ & $7.33 \pm 6.05$ & $4.68 \pm 4.33$ & 0.03 \\
ODI & $10.00 \pm 10.98$ & $5.88 \pm 7.35$ & 0.06 \\
BCTQ & $22.00 \pm 5.78$ & $20.85 \pm 4.51$ & 0.35 \\
SF-36 & $51.86 \pm 8.96$ & $54.57 \pm 7.11$ & 0.16
\end{tabular}

NDI: Neck Disability Index, ODI: Oswestry Disability Index, BCTQ: Boston Carpal Tunnel Syndrome Questionnaire, SF-36: Short Form-35. ${ }^{*} p<0.05$

한 그룹 간에 통계적으로 유의한차이를 보이지 않았다(Table 5).

\section{고 찰}

사회적 변화에 따라 삶의 양식과 문화, 개인의 신체활동과 정서가 변 화함을 예측할 수 있다. 코로나 19 로 인해 전 세계적으로 사람들의 삶 의 방식이 급격히 변화하고 있음에도 불구하고 이러한 변화를 반영한 신체적, 정신적 건강 상태를 비교한 연구는 부족하다. 이러한 이유로, 본 연구는 코로나 19 로 인한 사회적 거리두기에 따른 신체 활동량 감소 와 이와 반대로 디지털 기기 사용량 증가 등의 사회적 변화가 근골격계 질환 및 삶의 질에 미치는 영향을 확인하기 위하여 실시하였다.

본 연구의 대상자 총 135 명 중에 $64.4 \%$ 가 코로나 19 에 대한 사회적 거리두기를 잘 준수하였다. 코로나 19의 유행이 장기화되면서 '비대 면 서비스'에 대한 요구와 이용이 활성화되어 제한된 일상생활에서 편의와 만족을 증가시켜주고 있는 것이 사실이지만, ${ }^{26}$ 코로나 19 확산 예방을 위한 사회적 거리두기로 인해 변화된 생활 방식과 건강 상태 에 대한 부작용도 무시할 수 없는 실정이다. 실외 활동의 제약으로 신 체활동이 저하되어 피로감과 무력감, 면역 저하를 일으킨다. ${ }^{27}$ 신체 활동량이 낮은 수준이거나 근력 운동량이 주 1 회 이하일 경우에는 만성질환을 악화시켜 삶의 질을 떨어뜨린다. ${ }^{28}$ 
코로나 19 로 인한 신체 활동량의 감소는 온라인 활동량의 증가를 가져올 수 있다. 본 연구의 결과에서도 대상자들 중 하루 평균4시간 이상 컴퓨터 및 스마트폰을 사용하는 경우가 각각 $33.3 \%, 56.3 \%$ 로 제 일 많은 빈도수를 보였다. 방송통신위원회의 '코로나 19 에 따른 스마 트폰.PC방송프로그램 이용행태 조사결과에 따르면 전년 동월 대비 $\mathrm{PC}$ 이용시간이 약 $15 \%$ 증가했으며, 특히 코로나에 관련된 정보수집, 여가시간 활용 등을 위한 방송프로그램시청은 전년 동기간 대비 $67.3 \%$ 증가하였다. ${ }^{29}$ 또한, 마케팅. 빅데이터 분석 전문기관 NICE D\&R 의 보고서에 의하면 코로나 19 이후 국내 스마트폰 이용자들의 모바 일 앱 이용 시간이 전보다 약 4 시간 증가했다. ${ }^{30}$ 이 뿐만 아니라 컴퓨 터와 스마트폰을 이용한 인터넷 사용시간의 증가는 몰입과 중독에 영향을 주고 중독 수준에 이른 경우에는 신체적 불편감을 인식하지 못하게 되어 신체의 부담감을 가중시킨다. ${ }^{31}$ 본 연구에서도 컴퓨터 및 스마트폰 사용시간이 '4시간 이상'인 경우가 가장 많았을 뿐만 아니 라 컴퓨터와 스마트폰 사용에 따른 통증 유무 항목에서 '예'의 응답 률이 각각 $53.3 \%$ 와 $46.7 \%$ 로 나타나 이는 응답자의 다수가 통증을 느 끼는 것과 디지털 기기 사용량의 연관성을 증명해준다.

그러나 본 연구의 설문에서는 사회적 거리두기 스트레스 정도와 컴 퓨터 및 스마트폰 사용시간과의 상관계수가 각각 0.09 와 0.06 으로 상 관성이 낮게 나타났고 유의수준을 충족하지 못하였다. 그 이유는 첫 째, 코로나19로 인해 디지털 기기 평균 사용량이 4시간을 초과했지만 4 시간 이상 설문 문항에 대한 세분화가 부족하였다. 둘째, 코로나 19 이후 연령대별 디지털 기기 사용량 변화를 충분하게 반영하지 못했 다. 한 조사에 따르면, 코로나 19 이후 스마트폰 이용률 증가폭은 10 대 가 $22.37 \%$ 로 가장 크게 나타났고 뒤이어 60 대가 $16.25 \%$ 이었으며, $\mathrm{PC}$ 이 용률에서도 60 대가 $193.55 \%, 10$ 대가 $152.59 \%$ 이었다. ${ }^{29}$ 본 연구 대상자 의 $89.6 \%$ 를 차지하는 20 대와 30 대는 기존에도 디지털 기기를 학업과 근무를 위해 적극적으로 사용하고 있어 코로나19에 따른 디지털 기 기 사용량 증가폭이 적어 유의한 계수를 얻지 못했다고 사료된다.

이처럼 코로나 19 로 인한 가장 큰 사회적 변화는 사회적 거리두기 시행에 따른 온라인 활동의 증가이다. 관련된 선행연구에 따르면 과 도한 컴퓨터와 스마트폰 사용시간은 근골격계 질환인 VDT증후군을 발생시킨다. ${ }^{14}$ 선행연구에 따르면 영상표시 단말기 사용시간이 6시간 이상일 경우 어깨 $46.2 \%$, 허리 $33.2 \%$, 목 $33.1 \%$ 순으로 통증을 호소한 다. 뿐만 아니라 하루 3 시간 이상 스마트폰을 사용하는 경우 거북목 증후군을 악화시키고 등뼈 및 허리뼈 부위의 후방경사각을 증가시킨 다. ${ }^{12}$ 이러한 연구들은 본 연구의 사회적 거리두기 스트레스 정도와 목, 허리 통증 및 기능장애 평가척도인 NDI, ODI와의 상관관계 결과 에 대한 타당성을 뒷받침해준다. 비록 본 연구결과에서 상관계수가 각각 0.19 와 0.18 로 낮게 나타났지만 유의한 양의 상관성 $(\mathrm{p}<0.05)$ 을 보 이는 경향을 파악한 것 만으로도 의미 있는 결과라고 볼 수 있다. 즉,
코로나19로 인한 사회적 거리두기에 대한 스트레스가 높을수록 목 과 허리에 관한 통증 및 기능장애가 증가함을 의미한다.

각 변수별로 상관성이 낮게 나온 이유를 고찰해보면 첫째, 목의 통 증은 스트레스 외에도 자세에 따른 영향을 받기 때문이다. 컴퓨터 작 업 시 작업환경, 책상과 의자의 생김새, 모니터 및 키보드의 높이 등 에 따라 목의 통증을 유발하는 요인이 많음에도 불구하고 본 연구에 서는 컴퓨터 사용시 자세에 대한 설문을 포함시키지 못하였다. ${ }^{33}$ 또한 스마트폰 사용 시 작은 화면을 아래로 보는 동작은 목의 각도에 따라 목의 피로를 가중시킨다. 선행연구에 따르면 스마트폰을 바라보는 자 세에서 목의 각도가 $60^{\circ}$ 이면 목의 경사각의 좋지 않은 영향을 미치고 목통증과 연관된 등세모근에 피로를 가중시킨다. 그러므로 목의 각 도가 $0^{\circ}$ 일 경우가 목의 올바른 경사각 유지와 등세모근의 부담이 적 은 가장 바른 자세라고 한다. ${ }^{34}$ 하지만 본 연구의 설문조사에서는 스 마트폰 통화 시에 사용되는 얼굴방향 왼쪽, 오른쪽, 양쪽 여부만 설문 항목에 포함되어 스마트폰 사용 시에 다양한 자세에 따른 목의 피로 와 통증에 대한 영향을 반영하지 못하였다. 이를 보완하기 위해 목의 통증과 연관된 구체적인 인간공학적 추가설문조사가 필요하다. 둘 째, 선행연구에서 사용한 ODI 평가척도의 대상자 평균연령은 47.9세 인 반면 본 연구의 대상자의 40 세 이상은 $10 \%$ 에 불과했다. ${ }^{20}$ 또한 20 , 30 대에 비해 40대 이상의 ODI점수가 높고 특히, 60 대의 ODI점수 평 균은 18 점으로 가장 높았다. ${ }^{35}$ 이를 통해 근골격계 통증과 기능장애 는 개인의 신체활동량, 생활습관 외에도 나이로 인한 퇴행성 변화의 영향을 많이 받는다는 것을 알 수 있다. 이 외에도 규칙적으로 운동 을 하지 않는 대상자의 허리통증이 높다는 연구결과를 볼 때, ${ }^{36}$ 사회 적 거리두기가 장기화됨에 따라 후속 연구에서는 더 높은 상관계수 를 가질 것으로 예상된다.

사회적 거리두기 스트레스 정도와 $\mathrm{BCTQ}$ 와의 상관계수는 0.05 로 낮은 상관성을 보이고 유의수준을 충족하지 못하였다. 그 이유는 손 목터널 증후군이 식당일, 청소, 집안일을 하는 40-60대의 전업주부에 게서 빈발하고 농업, 미용사, 간호사, 약사, 책 제본과 같은 부자연스러 운 손 사용이 많은 직업에게서 주로 발생하기 때문이다. ${ }^{3738}$ 뿐만 아니 라 증상이 호발하는 평균연령은 37 세로 보고된다. ${ }^{38}$ 반면, 본 연구의 대상자 $80 \%$ 가 학업활동을 주로 하는 20 대로 손목터널 증후군이 호 발하는 직업군 및 연령대와는 거리가 멀다. 이를 보완하기 위해서는 추가적으로 스포츠 활동을 반영한 상지 근골격계 기능장애 평가도 구인 DASH (the disabilities of the arm, shoulder and hand) 설문을 추가 하여 유의미한 상관계수 얻기 위한 추가적인 연구가 필요할 것이다.

사회적 거리두기에 따른 스트레스 정도와 삶의 질의 관계에서는 상관계수 -0.17 ( $\mathrm{p}<0.0 .5)$ 로 낮은 상관성을 보였지만 통계적으로 유의 한 음의 상관성의 경향을 나타내는 것은 분명하다. 이는 코로나 19 로 인한 사회적 거리두기에 대한 스트레스가 높을수록 삶의 질이 감소 
함을 의미한다. 낮은 상관성이 나온 이유를 고찰해보면 첫째, 본 연구 대상자의 $80 \%$ 는 20 대 이기 때문이다. 이는 20 대가 40 대 이상 보다 문 제상황에서 스트레스를 적게 받고 대처능력이 높다는 연구결과로 알 수 있다. ${ }^{39}$ 또한 문제상황에서 직업이 없는 경우보다 직업이 있는 경우 가 스트레스가 높아지고 스트레스에 대한 신체증상이 늘어난다. ${ }^{40}$ 연 구대상자의 20 대의 대부분은 학생으로 사회활동을 하는 다른 연령 보다 스트레스에 상대적으로 적게 받아상관성이 적게 나타났다.

스트레스에 대한 측면에서 볼 때 목의 통증과 기능장애에 대한 척 도인 NDI가 사회적 거리두기에 대한 스트레스가 높은 그룹(이하, 그 룹A)의 값이 $7.33 \pm 6.05$, 스트레스가 낮은 그룹(이하, 그룹B)의 값이 $4.68 \pm 4.33$ 로 나타나 그룹A에서 목통증 지수가 더 높게 나타났으며 유의한 통계 값을 보여주었다. 이는 목통증은 정신적 요인과 유의한 연관성이 있으며, 스트레스 점수가 높고 우울 점수가 높을수록 목통 증에 대한 자각 가능성이 높다는 연구결과와도 같다. ${ }^{41}$ 또한 스트레 스가 중추신경계의 활성화를 유발하고 이는 근긴장을 증가시켜 근 육과 힘줄에 물리적 부하를 가함으로써 근골격계 질환 발생에 영향 을 미친다. 22,43 특히, 목통증과 연관된 등세모근이 다른 근육보다 감정 적, 신경적 자극에 대해 민감하다. ${ }^{44}$ 이 연구결과들은 현재 감염에 대 한 불안증이 극도로 높아져 있는 코로나 19 상황과 근골격계 통증이 연관되어 있음을 알 수 있게 한다.

마지막으로 본 연구의 제한점을 보완하기 위해 다음과 같은 추가 적인 연구가 필요하다. 첫째, 본 연구는 서울 및 경기 일부 지역의 성인 을 대상으로 하였기에 연구결과를 모든 사람에게 일반화하기에 무리 가 있으므로 다양한 지역의 사람들을 대상으로 표집한 연구가 필요 하다. 둘째, 본 연구는 참여 대상자 연령이 20대가 $80 \%$ 였기에 이 또한 일반화의 어려움이 있다. 추후 연구에서는 감염병에 취약한 10 대 청 소년, 활발하게 사회활동을 하는 30 대, 그리고 60대 이상의 고령자와 같이 다양한 연령층별 연구가 이루어져야 더욱 더 의미 있는 결과가 나올 것으로 본다. 셋째, 본 연구에 사용된 설문지는 코로나 19 이전의 선행연구들 바탕으로 구성하였기에 코로나19로 인한 변화된 사회상 을 반영한 문항구성이 부족하였다. 원격수업이나 재택근무의 여부, 코로나 19 이전과의 비교문항 등의 문항개발과 더불어 설문문항에 대 한 신뢰도 및 타당도 연구를 통해 질적인 자료 수집방법이 필요하다.

본 연구는 코로나 19 로 인한 사회적 거리두기와 디지털 기기의 사 용량, 근골격계 질환 및 삶의 질에 관한 통합적인 연구를 실시함에 그 의의가 있으며, 앞으로 본 연구의 결과가 이와 관련된 연구에서 기초 자료로 활용되기를 기대한다.

\section{REFERENCES}

1. Korea centers for disease control and prevention. Updates on COV-
ID-19 in republic of korea [Internet]. South Korea: 2020 August 1 [cited 2020 August 1]. Available from: http://ncov.mohw.go.kr/tcmBoardView. do? contSeq=358826.

2. Central disaster and safety countermeasures headquarters. Extensive social distancing for 15 days [Internet]. South Korea: 2020 March 3 [cited 2020 August 1]. Available from: http://ncov.mohw.go.kr/tcmBoardView.do?brdId=\&brdGubun=\&dataGubun $=\&$ ncvContSeq $=353673 \& \mathrm{c}$ ontSeq=353673\&board_id=140\&gubun=BDJ.

3. Koh KW. Physical activity guideline for social distancing during COVID-19. Korean J Health Educ Promot. 2020;37:109-12.

4. Jefferson T, Mar CBD, Dooley L et al. Physical interventions to interrupt or reduce the spread of respiratory viruses: systematic review. BMJ. 2008;336(7635):77-80.

5. Choi YH, Kim DH, Shin YJ. Teleworking in COVID-19: a pandemic perspective. CSPP. 2020;14(2):33-74.

6. Ministry of Education of Korea. Elementary school remote classes without smartphones [Internet]. South Korea: 2020 April 6 [cited 2020 August 1]. Available from: https://moe.go.kr/boardCnts/view.do?boardID= 294\&boardSeq=80214\&lev=0\&searchType $=$ null\&statusYN=W\&page $=1 \& \mathrm{~s}=$ moe\&m=020402\&opType $=\mathrm{N}$

7. Yoo DK, Jung SB, Choi SK. The analysis of differences in selection attributes of participants in online sports activities in the corona19 phenomenon. KJS. 2020;18(2):21-32.

8. Vos JD. The effect of COVID-19 and subsequent social distancing on travel behavior. TRIP. 2020;5:100121.

9. Kwon OJ. A case study of changes in the exercise behavior of the elderly by COVID-19. Korean J Sport Psychol. 2020;31(2):123-34.

10. Kim SY. A convergence study of stress caused by the epidemic of COVID-19, quality of life and positive psychological capital. Journal of the Korean Convergence Society. 2020;11(6):423-31.

11. Moon GS. The study for the potential injury of spinal column on using the smart phone with the postures. Korean J Sport Sci. 2016;25(4):152940.

12. Park JH. The influences of postures, daily habits, smartphone usage, physical activity levels and physical fitness on the spinal and pelvic deformations. Kyung Hee University. Dissertation of Doctorate Degree. 2018.

13. Kim CY. A correlation study on the between actuality of using a visual display terminal in university students and VDT syndrome. HanSeo University. Dissertation of Master's Degree. 2016.

14. Kim DS, Jung JH, Chae WS. The effect of acute active pc-video game on the upper extremity of adolescents. Korean J Sport Sci. 2016;27(4):74655.

15. Song JC, Lee SJ, Rho SC et al. Work related upper-extremity musculoskeletal disorders among visual display terminal (VDT) users in a telecommunication company in seoul, korea. Korean J Aerosp Environ Med. 2003;13(1):37-45.

16. Lee YR, Han SJ, Cho CM. Disaster experience, perception and perceived stress of nursing students. Korean J Stress Res. 2016;24(4):237-42.

17. Yoon TH, Cha TH, Hwang SH. The study on computer workstation, rest and musculoskeletal symptoms in high school students. J Korea Acad Industr Coop Soc. 2012;13(7):3037-47.

18. Eom SH, Choi SY, Park DH. An empirical study on relationship between symptoms of musculoskeletal disorders and amount of smartphone us- 
age. J Korea Saf Manag Sci. 2013;15(2):113-9.

19. Song KJ, Choi BW, Kim SJ et al. Cross-cultural adaptation and validation of the korean version of the neck disability index. J Korean Orthop Assoc. 2009;44(3):350-9.

20. Jeon CH, Kim DJ, Kim SK et al. Validation in the cross-cultural adaptation of the korean version of the oswestry disability index. J Korean Med Sci. 2006;21(6):1092-7.

21. Sambandam SN, Priyanka P, Gul A et al. Critical analysis of outcome measures used in the assessment of carpal tunnel syndrome. Int Orthop. 2008;32(4):497-504.

22. Koh Sb, Chang SJ, Kang MG et el. Reliability and validity on measurement instrument for health status assessment in occupational workers. Kor J Prev Med. 1997;30(2):251-66.

23. Bahk JW, Roh SC. Relationship between self-reported symptoms of work-related musculoskeletal disorders and health related quality of life. Ann Occup Environ Med. 2007;19(2):156-63.

24. Portney LG, Watkins MP. Foundations of clinical research: applications to practice. 3rd ed. Upper Saddle River, Prentice Hall, 2008:525.

25. Jung SH, Hwang UJ, Ahn SH et al. Lumbopelvic motor control function between patients with chronic low back pain and healthy controls: a useful distinguishing tool: The STROBE study. Medicine. 2020;99(15):1-5.

26. Kang HS, Lee YO. A theoretical review on the untact marketing of the COVID-19 period hospitality industry services. Journal of KOEN. 2020;14(7):161-73.

27. Jeon HM, Pan YH. A classification of type and user interaction model of online home training service in the social distancing environment -based on the service design perspective. Design Convergence Study. 2020;19(4):15-30.

28. Park SY. Associations with physical activity, chronic diseasem depression, and health-related quality of life. Korean J Sport Sci. 2014;25(2): 249-58.

29. Korea Communications Commission. Changes in smartphone and $\mathrm{pc}$ usage [Internet]. South Korea: 2020 June 2 [cited 2020 August 1]. Available from: https://kcc.go.kr/user.do?mode=view\&page=A05030000\&d $\mathrm{c}=\mathrm{K} 05030000$ \&boardId $=1113 \& \mathrm{cp}=1$ \&boardSeq $=49556$.

30. Nice Data \& Research. Changes in mobile app usage after COVID-19 [Internet]. South Korea: 2020 April 21 [cited 2020 August 1]. Available from: https:/www.appminder.co.kr/report.html?idx=11.
31. Ha JH. Psychiatric concepts and problems of internet addiction. J Korean Assoc Soc Psychiatry. 2001;6(2):110-4.

32. Yim SH, Lee YG, Cho JJ et al. Sympton prevalence of work-related musculoskeletal disorders and related factors among bank workers by visual dispaly terminal use. Ann Occup Environ Med. 1997;9(1):85-98.

33. Korhonen T, Ketola R, Toivonen R et al. Work related and individual predictors for incident neck pain among office employees working with video display units. Occup Environ Med. 2003;60(7):475-82.

34. Kim SJ, Jeong SY, Yoon TL. The Effect of visual feedback of head angles with using a mobile posture-aware system on craniocervical angle and neck and shoulder muscles fatigue during watching the smartphone. J Kor Phys Ther 2018:30(2):47-53.

35. Lee SJ. Oswestry low back pain disability index and related factors in patients with low back pain. J Kor Soc Phys Ther 2008;20(4):21-8.

36. Yi CH, Park JR, Cha AR et al. A study on the risk factors of low back pain in computer terminal operators. Ann Occup Environ Med. 1999;11(2): 264-75.

37. Buchberger W, Schön G, Strasser K et el. High-resolution ultrasonography of the carpal tunnel. J Ultrasound Med. 1991;10(10):531-7.

38. Kim JH, Han TR, Choi KH et al. A study of occupational history in idiopathic carpal tunnel syndrome. J Korean Acad Rehabil Med. 1996;20 (4):858-64.

39. Kim HS. Correlation between stress, coping patterns and physical symptom of cancer patient's caregiver. Korean J Adult Nurs. 2001;13(2):31726.

40. Jang SR, Lee SJ. A study on burden of family for caring of terminal cancer patients. J Korean Public Health Assoc. 2000;26(1):29-37.

41. Jung HJ, Song YM, Kim HY et al. Prevalence and associated factors of neck shoulder pain in high school students. J Korean Acad Fam Med. 2008;29(8):595-603.

42. Jones BE. Modulation of cortical activation and behavioral arousal by cholinergic and orexinergic systems. Ann N Y Acad Sci. 2008;1129(1): 26-34.

43. Kang DM, Kim YK, Kim YK et al. Job stress and musculoskeletal disease. J Korean Med Assoc. 2011;54(8):851-8.

44. Cha EJ, Kim KH. Impact of depression on adult material addiction among university students: testing the mediating effect of smartphone addiction. Journal of Youth Welfare. 2018;20(1):137-61. 